\title{
Plasticizer types and whey protein coatings on internal quality and shelf life of eggs
}

\section{stored for 42 days}

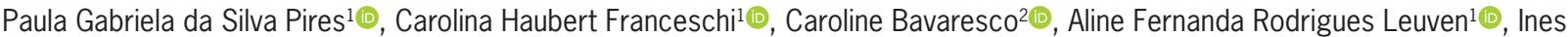 \\ Andretta ${ }^{*}$ (1)
}

\author{
Universidade Federal do Rio Grande do Sul/FA - Depto. de \\ Zootecnia, Av. Bento Gonçalves, 7712 - 91540-000 - Porto \\ Alegre, RS - Brasil. \\ 2Universidade Federal de Pelotas/FAEM - Depto. de \\ Zootecnia, Campus Universitário s/n - 96010-610 - Capão \\ do Leão, RS - Brasil. \\ *Corresponding author <ines.andretta@ufrgs.br>
}

Edited by: Pedro Esteves Duarte Augusto

Received August 24, 2020

Accepted November 07, 2020
ABSTRACT: Effects of plasticizer types and whey protein concentrate (WPC) as coatings were evaluated on internal quality and shelf life of eggs stored for 42 days. Eggs were coated with WPC at $8 \%$ solution combined with the plasticizers glycerol (GLY), sorbitol (SOR), and propylene glycol (PRO). The eggs were stored at $20^{\circ} \mathrm{C}$. Weight loss, Haugh Unit (HU), albumen and yolk $\mathrm{pH}$, and yolk index (YI) were evaluated weekly from day 0 to 42 days. After, electron microscopy of the eggshell structure was performed. The data was submitted to the analysis of variance and the effects of treatment, storage time, and the interaction between these factors were evaluated. There was significant interaction between factors (treatment and periods) for weight loss ( $p<0.0001)$, $\mathrm{HU}(p<0.0001)$, albumen $(p<0.0001)$, and yolk $\mathrm{pH}(p<0.0001)$, and $\mathrm{Yl}$ $(p<0.0001)$. After 42 days, uncoated eggs showed greater weight loss (5.4\%), compared to WPC+GLY, (3.8 \%), WPC+SOR (3.3\%) and WPC+PRO (3.9\%). Similar results were verified for $\mathrm{HU}$ at 42 days of storage. Uncoated eggs showed $\mathrm{HU}$ of 58.46 (B), while coated eggs showed higher values: WPC+GLY - 66.58 (A), WPC+SOR - 68.79 (A), and WPC + PRO - 71.53 (A). The plasticizers GLY, SOR and PRO, associated with WPC, demonstrated effectiveness in maintaining the quality of eggs throughout the 42 days of storage. However, WPC+SOR showed superiority in preserving quality integrity of eggs. This result can be related to the chemical structure of SOR, making the combination more efficient for storage.

Keywords: egg quality, glycerol, propylene glycol, sorbitol

\section{Introduction}

Several studies have investigated ways to delay degradation reactions in eggs after oviposition (Pires et al., 2020). Eggs shelf life (28 to 30 days, MAPA, 1990) could be longer, if some processes were used, such as refrigeration. However, the Brazilian legislation does not require eggs to remain under refrigeration until the final consumer purchases them.

Edible coatings can potentially extend the shelf life and improve the quality of food. Proteins are commonly used as film-forming materials, mainly because structures of proteins can be easily modified to achieve desirable film properties (Han, 2014). Several studies have demonstrated that protein coatings are effective in preserving egg quality with whey protein isolate (Kim et al., 2008), whey protein-pectin (DávalosSaucedo et al., 2018), rice protein concentrate (Pires et al., 2019), and lysozyme-chitosan (Yüceer and Caner, 2019; 2020). Whey proteins may be a good alternative for coating eggs (Caner and Yüceer, 2015; Almeida et al., 2016) due to various characteristics, mainly gelation capacity and water affinity (Boland, 2004). Caner and Yüceer (2015) reported that whey protein coating could extend the shelf life of eggs. These studies have been conducted using glycerol as plasticizer.

Coatings with proteins are extremely fragile and have low adhesion. In these formulations, plasticizers have shown to increase adherence to food (Assis and Britto, 2014). Plasticizers are non-volatile substances that, when added to a material, they change its mechanical and/or physical properties and often increase flexibility (Wan et al., 2005). Pires et al. (2020) evaluated the use of different plasticizers (glycerol, sorbitol, and propylene glycol) combined with rice protein concentrate and demonstrated that coatings were effective in preventing weight loss. However, the eggs coated with sorbitol presented better egg quality after 42 days of storage. Alleoni and Antunes (2004) used whey protein combined with glycerol and stated that coating effectiveness was reduced by its hydrophilic characteristic. Therefore, the association of protein coatings with plasticizers should be considered. This study assessed the effect of plasticizer types (glycerol, propylene glycol, or sorbitol) on the internal quality and changes on the eggshell of table eggs coated with whey protein during 42 days of storage at room temperature.

\section{Materials and Methods}

\section{Treatments}

Three hundred and thirty-six table eggs (ISA Brown hens) were randomly divided into four treatments: uncoated eggs and eggs coated only with plasticizers were used as a control treatment. The coatings were prepared at $8 \%(\mathrm{w} / \mathrm{w}$ protein) using whey protein coating - WPC (Lacprodan ${ }^{\circledR} 80$, Dinamarca) and the plasticizer types in water. The plasticizers used in the study were: GLY - glycerol (Fontana, Brazil), PRO - 
propylene glycol (Ineos, France), and SOR - sorbitol (Ingredion, Brazil). The plasticizers were then added to achieve a protein: plasticizer ratio $1: 2 \mathrm{w} / \mathrm{w}$. The solutions were kept on a magnetic stirrer for $5 \mathrm{~min}$ and then heated in water bath $\left(90^{\circ} \mathrm{C}\right)$ for $30 \mathrm{~min}$ (Antunes, 2003). Then, the temperature was reduced to $25^{\circ} \mathrm{C}$ and the $\mathrm{pH}$ adjusted to 10 with $1 \mathrm{~N} \mathrm{NaOH}$ solution, for the dissolution of proteins in the film-forming solution. All eggs were cleaned and submerged in coating solutions at $24{ }^{\circ} \mathrm{C}$ for $1 \mathrm{~min}$ to ensure that the entire eggshell surface was visibly covered by the coating. At the end of the procedure, the eggs were dried for $5 \mathrm{~min}$ at room temperature. The eggs were stored in plastic trays specific for eggs at room temperature and humity controlled $\left(20{ }^{\circ} \mathrm{C}_{i} \pm 65 \%\right)$ for up to 42 days.

\section{Analyzed variables}

During the trial, weight loss, Haugh unit, albumen $\mathrm{pH}$, and the yolk index were assessed weekly. At the beginning of the trial, 12 fresh eggs from each group were randomly separated and immediately submitted to quality evaluation to represent the characteristics of eggs with zero days of storage.

At the end of the experimental period, the electron microscopic structure of the shells was assessed.

\section{Weight loss}

The eggs were weighed individually using a digital precision ( $\pm 0.001 \mathrm{~g}$ ) scale (Bel Mark M 214A, Italy). The weight loss was calculated weekly in relation to the respective egg weight at the beginning of the trial according to Eq. 1.

Weight loss $=((\mathrm{FW}-\mathrm{IW}) / \mathrm{IW}) \times 100$

where: FW, final weight and IW, initial weight.

\section{Haugh Unit}

The albumen height was measured with a digital caliper (TMX PD - 150, China) at $10 \mathrm{~mm}$ from the yolk. After, the Haugh unit was calculated following Eq. 2. The eggs were graded based on the Haugh Unit (HU) results in: Class AA, when HU was higher than 72; Class A, eggs with HU from 71 to 60; Class B, eggs with HU from 59 to 31 ; or Class $\mathrm{C}$, when $\mathrm{HU}$ was lower than 30 (USDA, 2000).

Haugh unit $=100 * \log \left(\mathrm{H}-1.7 \mathrm{~W}^{0.37}+7.6\right) \quad$ Eq. (2)

where: $\mathrm{H}$, albumen height $(\mathrm{mm})$ and $\mathrm{W}$, egg weight (g).

\section{Albumen and yolk pH}

The albumen and yolk $\mathrm{pH}$ was determined using a digital pH meter (Kasvi model k39-2014B, Paraná, Brazil).

\section{Yolk index}

The yolk index was calculated as yolk height divided by yolk width, according to Caner and Yüceer (2015). Yolk height and width were measured with digital calipers without removing the albumen. The albumen and yolk were separated and then the $\mathrm{pH}$ was determined using a digital pH meter (Kasvi model k39-2014B, Brazil). The yolk index was calculated following Eq. 3.

Yolk index $=\mathrm{YH} / \mathrm{YW}$

Eq.(3)

where: YH, yolk height, and YW, yolk width.

\section{Electron microscopic: shell eggs}

Eggshells were segmented with scissors in apical, equatorial, and basal regions. Then, fragments of approximately $0.5 \mathrm{~cm}^{2}$ were removed from each egg region. The samples were mounted on a stub, coated with gold-palladium of $35 \mathrm{~nm}$ for $3 \mathrm{~min}$ (Sputter Coater - SCD 050, Germany), and analyzed through a scanning electron microscope (JEOL 6060, Japan) at a standard magnification of 250x.

\section{Statistical analysis}

The experimental design was completely randomized and composed of 12 replications per treatment. Each egg was considered an experimental unit. Data was submitted to the analysis of variance /general linear model) using software Minitab 18 (Minitab Inc. State College, PA). Statistical models included the effects of treatments (coating types), storage periods (weeks), and interaction (treatments by storage periods). Eventual differences $(p<0.05)$ were assessed with the Tukey multiple comparison test.

\section{Results and Discussion}

Eggs coated only with plasticizers were discarded after the first period of the experiment, as there was no coating formation. Due to their hydrophilic character, the eggs had a wet appearance to the touch, as well as the formation of "mold or mildew" on the surface.

\section{Weight loss}

Regarding egg weight loss, there was interaction between the effect of treatments and storage time (Figure 1). The effect of treatments in each period showed a positive response of the coatings after 21 days of storage, where the WPC + SOR treatment showed the lowest average weight loss (1.7 \%). There was a reduction in weight loss of eggs coated with WPC + GLY and WPC + PRO after 28 days of storage. According to the storage time (effect of the period), uncoated eggs or coated with WPC + GLY 
showed progressive loss of egg weight over 42 days of the experiment. Eggs coated with WPC + SOR and WPC + PRO lost weight more slowly.

Weight loss of eggs during storage is caused by evaporation of water and loss of carbon dioxide from the albumen through shell pores (Biladeau and Keener, 2009). Caner (2005) observed that the use of whey protein isolate at different concentrations decreased egg weight loss over four weeks of storage. These results are in accordance with Pires et al. (2020) which reported reduced weight loss in eggs coated with rice protein concentrate combined with glycerol, propylene glycol, and sorbitol.

\section{Haugh Unit}

The measurements of Haugh Unit (HU) were affected by treatments, storage time, and the interaction of these factors (Table 1). After 14 days of storage, eggs coated with WPC + PRO presented a higher HU

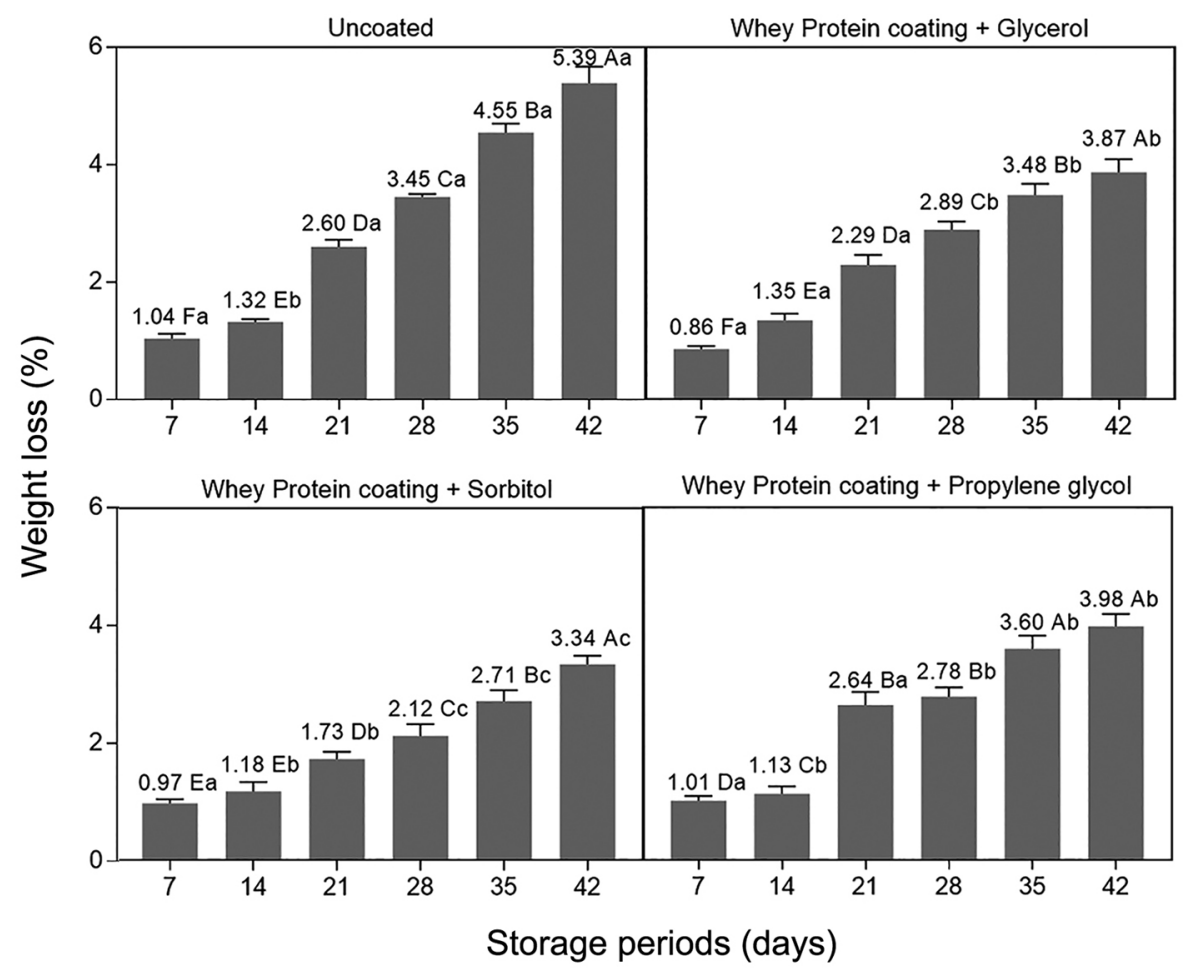

Figure 1 - Effect of different types of plasticizers associated with whey protein concentrate on weight loss of eggs stored at $20^{\circ} \mathrm{C}$ for up to 42 days (means \pm standard deviations - information was collected in 12 eggs per treatment). Significant interaction - Treatments ${ }^{*}$ Storage periods $(p<0.05)$. Means with different lowercase letters are significantly different, treatment effect within each period $(p<0.05)$. Means with different capital letters are significantly different, period effect within each treatment $(p<0.05)$.

Table 1 - Effect of whey protein concentrate and different plasticizer coatings on Haugh unit (HU) and egg grade ${ }^{1}$ (designated after each mean between parentheses) during 42 days of storage at $20^{\circ} \mathrm{C}^{2}$.

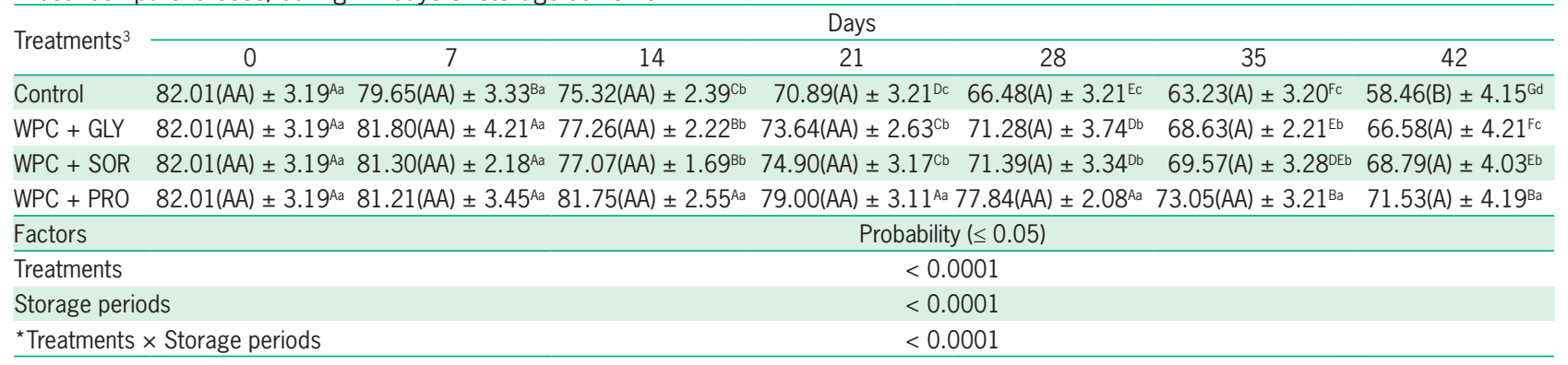

'Egg grades: $\mathrm{AA}$ if $\mathrm{HU}>72$; $\mathrm{A}$ if $\mathrm{HU}=71-60$; $\mathrm{B}$ if $\mathrm{HU}=59-31$; $\mathrm{C}$ if $\mathrm{HU}<30$. ${ }^{2}$ Data are expressed as means (egg grades) \pm standard deviations. Information was collected in 12 eggs per treatment. ${ }^{3} \mathrm{WPC}=$ Whey protein coating; GLY = Glycerol; SOR = Sorbitol; PRO = Propylene glycol. * ${ }^{*}$ Interaction. ${ }^{A F}$ Means in the same row with different capital letters are significantly different. adMeans in the same column with different lowercase letters are significantly different. 
compared to the other treatments. At the end of the storage period, eggs coated with WPC + GLY had the lowest HU compared to the other coated eggs. Similar results were observed for egg weight loss, where the WPC + GLY treatment showed greater weight loss, compared to the WPC + SOR and WPC + PRO groups. This was probably due to the coating quality (protein + plasticizer). The use of SOR and PRO as a plasticizer may have increased adherence of WPC to the eggs, reducing weight loss during storage, keeping the internal quality of the egg and a higher degree of HU classification.

Uncoated eggs showed a decrease of quality from grade "AA" to "A" after 21 days and to grade " $\mathrm{B}$ " after 42 days of storage. Meanwhile, eggs coated with $\mathrm{WPC}+\mathrm{GLY}$ or WPC + SOR changed from "AA" to "A" after 28 days of storage. In this assessment, the best results were observed for eggs coated with $\mathrm{WPC}+\mathrm{PRO}$, which kept grade "AA" up to 35 days of storage at $20^{\circ} \mathrm{C}$. These results agree with Pires et al. (2020), who reported that eggs coated with rice protein concentrate associated with PRO or SOR changed from "AA" to "A" only after 35 days of storage, while eggs coated with rice protein concentrate and GLY changed from "AA" to "A" at the end of 28 days of storage.

The reduction of $\mathrm{HU}$ value can be attributed to ovomucine proteolysis, cleavage of disulfide bridges, or by the interaction between $\alpha$ and $\beta$ ovomucines (Oliveira and Oliveira, 2013). The use of coatings is a suitable tool to preserve the internal egg quality (grade A maintenance) for a longer period, extending the product shelf life and reducing wastage.

\section{Albumen and yolk $\mathrm{pH}$}

The albumen and yolk $\mathrm{pH}$ varied over the storage period (Table 2). There was interaction between treatment and storage time for the $\mathrm{pH}$. The positive action of the coatings on the albumen $\mathrm{pH}$ was observed after seven days of storage. In the periods of 14,21 , and 28 days, the $\mathrm{WPC}+\mathrm{PRO}$ coating was less effective. In the periods of $14,28,35$, and 42 days, the treatments WCP + GLY and WCP + SOR presented the lowest means for this variable. The analysis of the treatments individually over 42 days of storage (effect of the period) showed that uncoated eggs displayed a progressive increase in the albumen $\mathrm{pH}$ and although the albumen $\mathrm{pH}$ increased in coated eggs, it occurred gradually and more slowly.

The albumen $\mathrm{pH}$ of a fresh egg usually ranges from 7.6 to 8 . The increasing loss of carbon dioxide through the shell causes albumen alkalization, raising the $\mathrm{pH}$ to 9.4 after 14 days of storage (Silversides and Scott, 2001; Biladeau and Keener, 2009). Thus, the albumen pH could be used as an indicator of freshness of the eggs. Pires et al. (2020) observed lower albumen $\mathrm{pH}$ in eggs coated with rice protein concentrate plus SOR after 42 days of storage, followed by the treatments with GLY and $\mathrm{PRO}$, which showed intermediate values for the control (uncoated eggs). Kim et al. (2008) observed that the use of chitosan with different plasticizers markedly slowed the increase in albumen $\mathrm{pH}$.

The yolk $\mathrm{pH}$ showed a significant difference between the different types of coatings after 21 days of storage. Eggs coated with WPC + GLY and WCP + SOR showed lower $\mathrm{pH}$ values compared to uncoated eggs. There was

Table 2 - Effect of whey protein concentrate and different plasticizer coatings on albumen and yolk pH during 42 days of storage at $20{ }^{\circ} \mathrm{C}^{1}$.

\begin{tabular}{|c|c|c|c|c|c|c|c|}
\hline \multirow[b]{2}{*}{ Treatments $^{2}$} & \multicolumn{7}{|c|}{ Days } \\
\hline & 0 & 7 & 14 & 21 & 28 & 35 & 42 \\
\hline \multicolumn{8}{|c|}{ Albumen $\mathrm{pH}$} \\
\hline Control & $8.04 \pm 0.11^{\mathrm{Ea}}$ & $8.34 \pm 0.08^{\mathrm{Da}}$ & $8.70 \pm 0.10^{\mathrm{cb}}$ & $9.08 \pm 0.16^{\mathrm{Ba}}$ & $9.21 \pm 0.18^{\mathrm{Ba}}$ & $9.45 \pm 0.16^{\mathrm{Aa}}$ & $9.48 \pm 0.14^{\mathrm{Aa}}$ \\
\hline $\mathrm{WPC}+\mathrm{GLY}$ & $8.04 \pm 0.11^{\mathrm{Da}}$ & $8.18 \pm 0.13^{\text {CDab }}$ & $8.44 \pm 0.14^{\mathrm{BCC}}$ & $8.58 \pm 0.15^{\mathrm{Bb}}$ & $8.67 \pm 0.10^{A B b}$ & $8.69 \pm 0.09^{A B d}$ & $8.91 \pm 0.07^{\mathrm{Ac}}$ \\
\hline WPC + SOR & $8.04 \pm 0.11^{\mathrm{ca}}$ & $7.89 \pm 0.10^{c b}$ & $8.51 \pm 0.17^{B C}$ & $8.90 \pm 0.10^{\mathrm{Aa}}$ & $8.76 \pm 0.14^{\mathrm{Ab}}$ & $8.97 \pm 0.11^{A c}$ & $8.96 \pm 0.10^{A C}$ \\
\hline$W P C+P R O$ & $8.04 \pm 0.11^{\mathrm{ca}}$ & $7.74 \pm 0.12^{\mathrm{Db}}$ & $8.95 \pm 0.13^{\mathrm{Ba}}$ & $8.95 \pm 0.10^{\mathrm{Ba}}$ & $9.14 \pm 0.12^{\text {Aba }}$ & $9.27 \pm 0.14^{\mathrm{Ab}}$ & $9.27 \pm 0.18^{\mathrm{Ab}}$ \\
\hline Factors & & \multicolumn{6}{|c|}{ Probability $(\leq 0.05)$} \\
\hline Treatments & & \multicolumn{6}{|c|}{$<0.0001$} \\
\hline Storage periods & & \multicolumn{6}{|c|}{$<0.0001$} \\
\hline${ }^{*}$ Treatments $\times \mathrm{S}$ & ge periods & \multicolumn{6}{|c|}{$<0.0001$} \\
\hline \multicolumn{8}{|l|}{ Yolk pH } \\
\hline Control & $6.24 \pm 0.08^{c a}$ & $6.45 \pm 0.10^{\mathrm{Ba}}$ & $6.58 \pm 0.07^{\mathrm{Ba}}$ & $6.91 \pm 0.08^{\mathrm{Aa}}$ & $6.96 \pm 0.10^{\mathrm{Aa}}$ & $6.96 \pm 0.07^{\text {Аа }}$ & $7.00 \pm 0.10^{\mathrm{Aa}}$ \\
\hline $\mathrm{WPC}+\mathrm{GLY}$ & $6.24 \pm 0.08^{\mathrm{Ba}}$ & $6.25 \pm 0.04^{\mathrm{Ba}}$ & $6.66 \pm 0.10^{\mathrm{Aa}}$ & $6.86 \pm 0.07^{\mathrm{Aab}}$ & $6.87 \pm 0.06^{\mathrm{Aa}}$ & $6.88 \pm 0.05^{\mathrm{Aa}}$ & $6.90 \pm 0.09^{\mathrm{Aa}}$ \\
\hline$W P C+S O R$ & $6.24 \pm 0.08^{\mathrm{Da}}$ & $6.38 \pm 0.06^{\mathrm{CDa}}$ & $6.64 \pm 0.02^{\mathrm{ABCDa}}$ & $6.44 \pm 0.11^{\mathrm{BCDb}}$ & $6.92 \pm 0.07^{\mathrm{ABa}}$ & $6.87 \pm 0.08^{\mathrm{ABCa}}$ & $7.01 \pm 0.11^{\mathrm{Aa}}$ \\
\hline$W P C+P R O$ & $6.24 \pm 0.08^{\mathrm{ca}}$ & $6.54 \pm 0.07^{\mathrm{BCa}}$ & $6.61 \pm 0.06^{\mathrm{ABCa}}$ & $6.70 \pm 0.12^{\text {ABab }}$ & $6.84 \pm 0.06^{\mathrm{ABa}}$ & $6.97 \pm 0.03^{\mathrm{ABa}}$ & $6.99 \pm 0.04^{\text {Аа }}$ \\
\hline Factors & & \multicolumn{6}{|c|}{ Probability $(\leq 0.05)$} \\
\hline Treatments & & \multicolumn{6}{|c|}{$<0.0001$} \\
\hline Storage periods & & \multicolumn{6}{|c|}{$<0.0001$} \\
\hline${ }^{\star}$ Treatments $\times \mathrm{S}$ & ge periods & \multicolumn{6}{|c|}{$<0.0001$} \\
\hline
\end{tabular}

${ }^{1}$ Data are expressed as means \pm standard deviations. Information was collected in 12 eggs per treatment. ${ }^{2} \mathrm{WPC}=$ Whey protein coating; GLY = Glycerol; SOR =

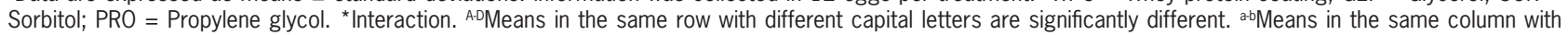
different lowercase letters are significantly different. 
a progressive increase in the yolk $\mathrm{pH}$ over the period; however, the coated eggs did not show differences even when compared to uncoated eggs at 42 days of storage.

The yolk $\mathrm{pH}$ also increased during the storage period, probably due to the incorporation of water into the yolk structure (Oliveira and Oliveira, 2013). Biladeau and Kenner (2009) documented a maximum increase in yolk pH from 6.01 to 6.27. Pires et al. (2020) observed that the yolk $\mathrm{pH}$ in coated eggs was lower than in uncoated eggs from seven days of storage, regardless of the plasticizer used. However, there was no influence of coating and plasticizers on the yolk $\mathrm{pH}$ after 42 days of storage. Despite some differences observed through the project, the yolk $\mathrm{pH}$ was similar among treatments after 42 days of storage.

\section{Yolk index}

There was an effect of treatments, storage periods, and interaction between these factors (Figure 2).

After 14 days of storage, the positive effect of coatings on the yolk index (YI) was evident. Eggs coated with WPC + GLY, WPC + SOR, WPC + PRO after 14, 21,28 , and 35 days of storage presented higher averages than uncoated eggs. At 42 days, only the coatings with WPC + GLY and WCP + PRO differed from the control treatment. The effect of storage time on YI was clearly seen in uncoated eggs, where there was a progressive reduction of YI over the period. The coating with WPC + SOR was not efficient in keeping YI over 42 days, while WPC + GLY and WPC + PRO was more efficient in preserving the yolk quality through YI.

The YI is another measurement of egg freshness and is based on the relationship between yolk height and width (Yüceer and Caner, 2014). In general, the YI decreased with increasing storage time. Eggs effectively coated reduced the mass transfer (loss of water and carbon dioxide) of the albumen through the shell during storage. Consequently, this process inhibits liquefaction of the albumen and water absorption by the yolk thus minimizing the reduction in yolk quality. Caner and Yüceer (2015) observed a positive effect of coatings in keeping the yolk quality through YI. Almeida et al. (2016) and Pires et al. (2019) also reported the benefit of using protein coatings to keep internal egg quality during storage.

\section{Electron microscopic: eggshell}

Eggshells coated with WPC showed lower surface porosity in the ultrastructural assessment (Figures 3A to 3D). This is probably due to great sealing properties in WPC coating, which may help prevent the evaporation of moisture and gases.

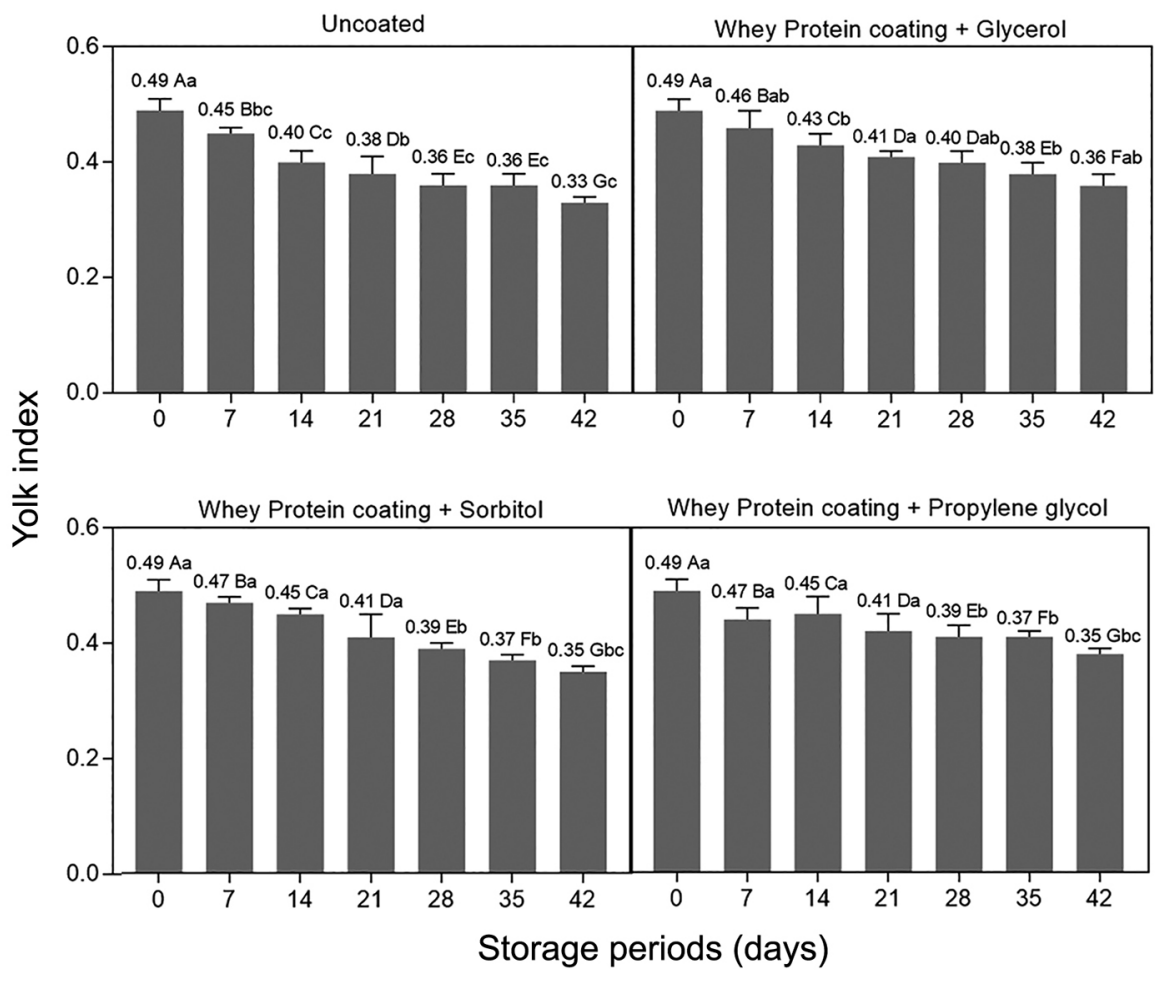

Figure 2 - Effect of different types of plasticizers associated with whey protein concentrate yolk index of eggs stored at $20^{\circ} \mathrm{C}$ for up to 42 days (means \pm standard deviations - information was collected in 12 eggs per treatment). Significant interaction - Treatments ${ }^{\star}$ Storage periods ( $p$ $<0.05)$. Means with different lowercase letters are significantly different, treatment effect within each period $(p<0.05)$. Means with different capital letters are significantly different, period effect within each treatment $(p<0.05)$. 

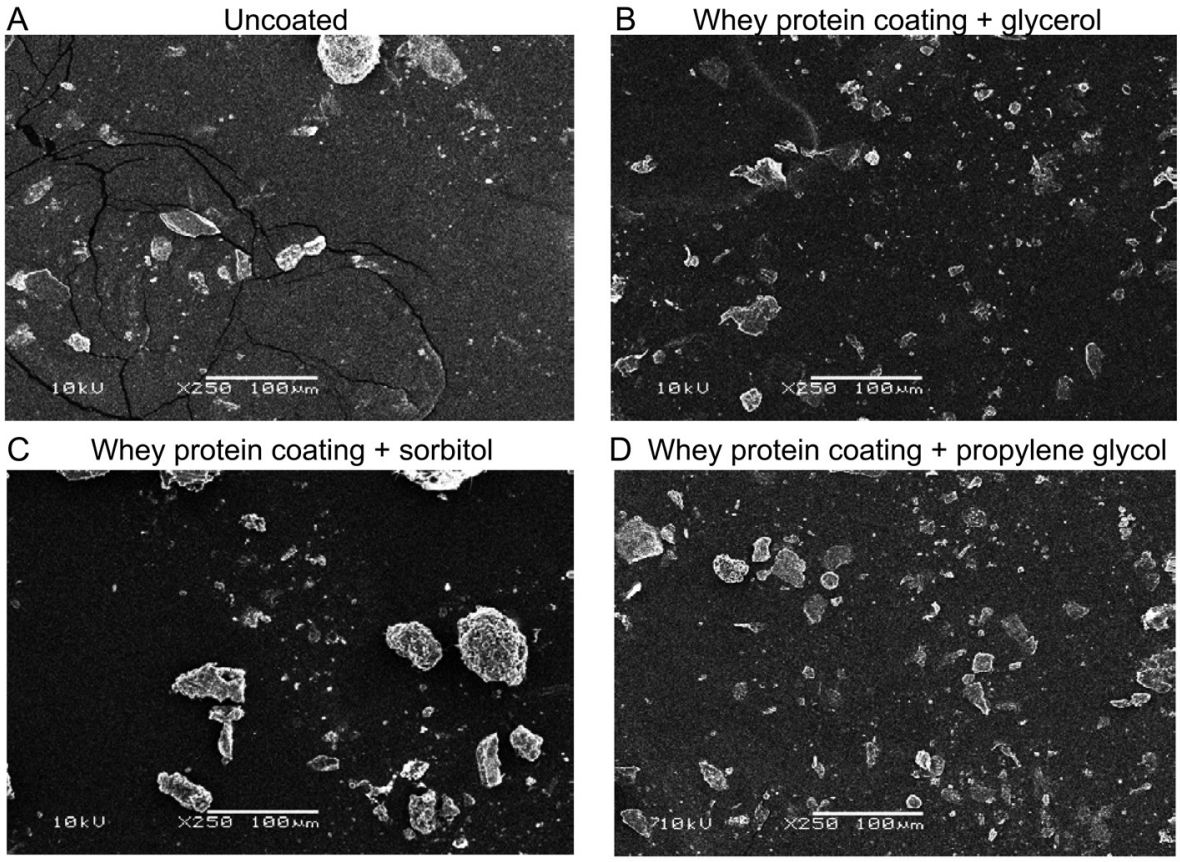

Figure 3 - Scanning electron microscopy (250x) of uncoated eggshell (A) and coated eggs (B to D) after 6 weeks of storage.

Egg quality responses are related to gas exchanges between the egg and the environment. Therefore, the greater the adhesion and the thickness of the coating, the greater the protection provided against gas exchange and therefore the longer shelf life of the food. The most direct answer to assess egg quality is weight loss. In our study, eggs coated with WPC+SOR showed lower weight loss compared to the other treatments from 21 days of storage until the end of the trial. After 42 days, eggs coated with WPC + GLY or WPC + PRO showed similar weight loss, which was lower than the control treatment; nevertheless, higher than the weight loss reported in the eggs coated with WPC+SOR.

McHugh and Krochta (1994) affirm that the increase of the glycerol content raises the permeability to the gases of hydrophilic films; therefore, this additive binds to the biopolymer molecules, increasing mobility and decreasing density between molecules, facilitating the passage of gases through the material. Water solubility is an important factor when choosing the plasticizer. In some applications, coatings with adequate insolubility are essential to provide water resistance thus increasing the product shelf life (Perezgago and Krochta, 2001; Yin et al., 2007). Plasticizers that are less hygroscopic than GLY (such as SOR) can promote greater water barrier properties in protein-based coating (Wan, 2005).

\section{Conclusion}

The glycerol, propylene glycol, and sorbitol plasticizers associated to whey protein coatings were effective to reduce weight loss and preserve the albumen and yolk quality of stored eggs for up to 42 days a $20{ }^{\circ} \mathrm{C}$. Loss of egg quality was reduced more effectively with the use of the whey protein concentrate + sorbitol. Thus, it is recommended to coat eggs stored for up to 42 days with WPC + SOR.

\section{Acknowledgments}

We acknowledge the Center for Microscopy and Microanalysis of Federal University of Rio Grande do Sul. Arla Foods Ingredients S.A. for the donation of the WPC. We also thank Granja Filippsen for the donation of the eggs.

\section{Authors' Contributions}

Conceptualization: Pires, P.G.S. Data acquisition: Pires, P.G.S.; Franceschi, C.H. Data analysis: Pires, P.G.S.; Bavaresco, C. Design of methodology: Pires, P.G.S.; Leuven, A.F.R. Writing and editing: Pires, P.G.S.; Bavaresco, C.; Andretta, I.; Leuven, A.F.R.

\section{References}

Alleoni, A.C.C.; Antunes, A.J. 2004. Internal quality of eggs coated with whey protein concentrate. Scientia Agricola 61: 276-280.

Almeida, D.S.; Schneider, A.F.; Yuri, F.M.; Machado, B.D.; Gewehr, C.E. 2016. Egg shell treatment methods effect on commercial eggs quality. Ciência Rural 46: 336-341.

Antunes, A.J. 2003. Bovine Whey Protein Functionality = Funcionalidade de Proteínas do Soro de Leite Bovino. Editora Manole, São Paulo, SP, Brazil (in Portuguese). 
Assis, O.B.G.; Britto, D. 2014. Review: edible protective coatings for fruits: fundamentals and applications. Brazilian Journal of Food Technology 17: 87-97 (in Portuguese, with abstract in English).

Biladeau, A.; Keener, K. 2009. The effects of edible coating on chicken egg quality under refrigerated storage. Poultry Science 88: 1266-1274.

Boland, M. 2004. Whey proteins. p. 30-55. In: Phillips, G.O.; Williams, P.A. Proteins in food processing. 2ed. Woodhead Publishing, Cambridge, England.

Caner, C. 2005. Whey protein isolate coating and concentration effects on egg shelf life. Journal of the Science of Food and Agriculture 85: 2143-2148.

Caner, C.; Yüceer, M. 2015. Efficacy of various protein-based coating on enhancing the shelf life of fresh eggs during storage. Poultry Science 94: 1665-1677.

Dávalos-Saucedo, C.A.; Rossi-Márquez, G.; Regalado-González, C.; Alonzo-Macías, M.; Di Pierro, P. 2018. Application of transglutaminase crosslinked whey protein-pectin coating improves egg quality and minimizes the breakage and porosity of eggshells. Coatings 8: 438.

Han, J.H. 2014. Edible films and coatings: a review. p. 213-255. In: Han, J.H. Innovations in food packaging. 2ed. Elsevier, Amsterdam, The Netherlands.

Kim, S.H.; No, H.K.; Prinyawiwatkul, W. 2008. Plasticizer types and coating methods affect quality and shelf life of eggs coated with chitosan. Journal of Food Science 73: 111-117.

McHugh, T.H.; Krochta, J.M. 1994. Sorbitol vs glycerol: plasticized whey protein edible films: integrated oxygen permeability and tensile property evaluation. Journal of Agricultural and Food Chemistry 42: 841-845.

Ministério da Agricultura, Pecuária e Abastecimento [MAPA]. 1990. Ordinance $n^{\circ} 1,21$ February of 1990. Meat and Derivatives Inspection Division. General rules for the inspection of eggs and derivatives = Divisão de Inspeção de Carnes e Derivados: Normas Gerais de Inspeção de Ovos e Derivados. MAPA, Brasília, DF, Brazil (in Portuguese).

Oliveira, B.L.; Oliveira, D.D. 2013. Egg Quality and Technology = Qualidade e Tecnologia de Ovos. Editora UFLA, Lavras, MG, Brazil. (in Portuguese).

Perezgago, M.B.; Krochta, J.M. 2001. Denaturation time and temperature effects on solubility, tensile properties, and oxygen permeability of whey protein edible films. Journal of Food Science 66: 705-710.
Pires, P.G.S.; Bavaresco, C.; Leuven, A.F.R.; Gomes, B.C.K.; Souza, A.K.; Santaiana, B.P.; Kindlein, L.; Andretta, I. 2020. Plasticizer types affect quality and shelf life of eggs coated with rice protein. Journal of Food Science and Technology 57: 971979.

Pires, P.G.S.; Machado, G.S.; Franceschi, C.H.; Kindlein, L.; Andretta, I. 2019. Rice protein coating in extending the shelflife of conventional eggs. Poultry Science 98: 1918-1924.

Pires, P.G.S.; Pires, D.G.S.; Cardinal, K.M.; Bavaresco, C. 2020. The use of coating in eggs: a systematic review. Trends in Food Science \& Technology 106: 312-321.

Silversides, F.; Scott, T. 2001. Effect of storage and layer age on quality of eggs from two lines of hens. Poultry Science 80: 1240-1245.

United States Department of Agriculture [USDA]. 2000. United States Standards, Grades, and Weight Classes for Shelleggs. AMS 56.210. USDA, Washington, DC, USA.

Yin, S.W.; Tang, C.H.; Wen, Q.B.; Yang, X.Q. 2007. Properties of cast films from hemp (Cannabis sativa L.) and soy protein isolates: a comparative study. Journal of Agricultural and Food Chemistry 55: 7399-7404.

Yüceer, M.; Caner, C. 2020. The effects of ozone, ultrasound and coating with shellac and lysozyme-chitosan on fresh egg during storage at ambient temperature. Part II. Microbial quality, eggshell breaking strength and FT-NIR spectral analysis. International Journal of Food Science and Technology 55: 16291636.

Yüceer, M.; Caner, C. 2019. The effects of ozone, ultrasound and coating with shellac and lysozyme-chitosan on fresh egg during storage at ambient temperature. Part 1. Interior quality changes. International Journal of Food Science and Technology 55: 259-266.

Yüceer, M.; Caner, C. 2014. Antimicrobial lysozyme-chitosan coatings affect functional properties and shelf life of chicken eggs during storage. Journal of the Science of Food and Agriculture 94: 153-162.

Wan, V.C.H.; Kim, M.S.; Lee, S.Y. 2005. Water vapor permeability and mechanical properties of soy protein isolate edible films composed of different plasticizer combinations. Journal of Food Science 70: 387-391. 